\title{
Hubungan Kualitas Pelayanan Rawat Jalan Dengan Kepuasan Pasien Thalassemia Di RSUD Kabupaten Indramayu
}

\author{
Relationship between Outpatient Service Quality and Satisfaction of Thalassemia Patients in \\ Indramayu District Hospital
}

\section{Heny Ramayani ${ }^{1}$, Tayong Siti Nurbaeti ${ }^{2}$, Sutangi $^{3}$ \\ 1,2,3 Program Studi Kesehatan Masyarakat Universitas Wiralodra e-mail: t.siti.nurbaeti@gmail.com}

\begin{abstract}
Abstrak
Pasien thalassemia adalah pasien yang membutuhkan pelayanan kesehatan secara rutin dan terus menerus selama hidupnya. Kualitas pelayanan rawat jalan menentukan keberhasilan pengobatan dan perawatan pasien thalassemia. Tujuan penelitian ini untuk mengetahui karakteristik pasien thalassemia, gambaran kualitas pelayanan rawat jalan, tingkat kepuasan pasien thalassemia, dan hubungan kualitas pelayanan rawat jalan dengan kepuasan pasien thalassemia di RSUD Kabupaten Indramayu.

Jenis penelitiannya adalah analitik observasional dengan rancangan cross sectional. Teknik pengambilan sampel yang digunakan yaitu total sampling. Instrumen penelitian ini adalah kuesioner. Analisis data menggunakan analisis univariat dan analisis bivariat dengan uji chi-square. Hasilnya karakteristik pasien thalassemia sebanyak 40 orang $71,4 \%$ adalah anakanak, 36 orang $64,3 \%$ berjenis kelamin perempuan dan 36 orang $64,3 \%$ berpendidikan SD. Kualitas pelayanan rawat jalan di RSUD Kabupaten Indramayu 67,9\% pasien merasa sudah baik, dan $32,1 \%$ merasa masih kurang baik. Dari 56 orang responden $64,3 \%$ pasien merasa puas terhadap pelayanan rawat jalan dan hanya $35,7 \%$ merasa kurang puas. Ada hubungan antara kualitas pelayanan rawat jalan dengan kepuasan pasien thalassemia di RSUD Kabupaten Indramayu. Kualitas pelayanan rawat jalan di RSUD Indramayu sudah baik dan sebagian besar pasien thalassemia merasa puas.
\end{abstract}

Kata Kunci: Pasien thalassemia, Kualitas pelayanan rawat jalan, Kepuasan pasien.

\section{Abstract}

Thalassemia patients are people who need health services routinely during his lifetime. Outpatient service quality determined the success of treatment of thalassemia patients. This study was aimed to identify the characteristics of thalassemia patients, picture of outpatient service quality, thalassemia patient satisfaction level and the correlation between outpatient service quality and thalassemias patients satisfaction in Indramayu Regional Public Hospital. The type of this study was analitic observasional with cross sectional design. The sampling technique used is total sampling. The instrument of this research is questionnaire. Data analysis used univariate and bivariate analysis with chisquare test. Characteristics of thalassemia patients as many as 40 people $71.4 \%$ were children, 36 people $64.3 \%$ female sex and 36 people $64.3 \%$ elementary schooled. Outpatient service quality in Indramayu Regional Public Hospital is $67.9 \%$ patient feel good, and $32.1 \%$ feel still less good. From 56 respondents $64.3 \%$ of patients were satisfied with outpatient services and only $35.7 \%$ felt less satisfied. There were significant correlations between outpatient service quality and thalassemia patients satisfaction in Indramayu Regional Public Hospital. The quality of outpatient services at Indramayu Regional Public Hospital is good and most thalassemia patients are satisfied

Keywords: Thalassemia Patients, Outpatient Service Quality, Thalassemia Patients Satisfaction.

\section{Pendahuluan}

Rumah sakit sebagai salah satu sarana kesehatan yang memberikan pelayanan kesehatan kepada masyarakat memilki peran yang sangat strategis dalam mempercepat peningkatan derajat kesehatan masyarakat, oleh karena itu rumah sakit dituntut untuk memberikan pelayanan yang bermutu sesuai dengan standar yang ditetapkan dan dapat menjangkau seluruh lapisan masyarakat.

Pelayanan yang baik akan memberikan kepuasan kepada pelanggannya. Kepuasan dapat membentuk persepsi, dan hal ini dapat memposisikan produk perusahaan di mata 
pelanggannya. Pihak rumah sakit perlu mengetahui kualitas pelayanan yang telah diberikan, dan sampai seberapa jauh mempengaruhi kepuasan konsumennya. Hal tersebut penting sebagai acuan dalam pembenahan kualitas pelayanan, sehingga pelayanan yang diberikan bisa memberikan kepuasan pada tingkat yang optimal. ${ }^{1}$

Pelayanan rawat jalan di rumah sakit merupakan bagian yang tidak dapat dipisahkan dari pelayanan rumah sakit secara keseluruhan. Menurut Standar Pelayanan di Rumah Sakit menyebutkan bahwa kualitas pelayanan rawat jalan rumah sakit adalah pelayanan yang menunjuk pada tingkat kesempurnaan pelayanan dalam menimbulkan kepuasan pasien sesuai dengan tingkat kepuasan ratarata masyarakat, serta menyelenggarakannya sesuai dengan standar pelayanan kesehatan.

Salah satu pelayanan kesehatan rawat jalan di rumah sakit adalah pelayanan pengobatan dan perawatan thalassemia. Thalassemia merupakan penyakit anemia hemolitik dimana terjadi kerusakan sel darah merah di dalam pembuluh darah sehingga umur eritrosit menjadi pendek kurang dari 120 hari. $^{2}$ Anakanak dengan thalassemia mayormembutuhkan dan transfusi darah yang teratur untuk untuk mempertahankan hidupnya.Anak juga harus mengkonsumsi obat kelasi besi yang bertujuan untuk mengurangi kelebihan zat besi akibat transfusi darah yang dilakukan secara rutin dalam jangka waktu yang lama. ${ }^{3}$

Di Indonesia beberapa data menunjukkan bahwa ada sekitar ratusan ribu orang pembawa sifat thalassemia yang beresiko diturunkan pada anak mereka serta data lain yang menemukan bahwa $6-10 \%$ penduduk Indonesia merupakan pembawa gennya. Penderita thalassemia mayor di Indonesia sudah tercatat sekitar 5.000 orang, selain yang belum terdata atau kesulitan mengakses layanan kesehatan. Angka penderita di dunia lebih besar, yaitu setiap tahunnya ada sekitar 100.000 penderita baru yang lahir dari pasangan pembawa gen. ${ }^{4}$
Berdasarkan studi pendahuluan yang dilakukan dengan cara wawancara langsung di RSUD Kabupaten Indramayu menunjukkan bahwa dari 5 orang responden thalassemia 3 orang menyatakan kurang puas dengan pelayanan rawat jalan di RSUD Kabupaten Indramayu.

Hasil wawancara peneliti kepada sebagian kecil pasien rawat jalan yang menunggu, mereka mengeluhkan dalam hal lamanya menunggu untuk mendapatkan pelayanan. Hal ini tidak sesuai dengan Peraturan Menkes RI No. 129 Tahun 2008 tentang Standar Pelayanan Minimal Rumah sakit, yang menyatakan bahwa standar pelayanan waktu tunggu pelayanan rawat jalan adalah $\leq 60$ menit.

Permasalahan lain di pelayanan rawat jalan RSUD Kabupaten Indramayu yaitu tidak tersedia kotak saran, menyebabkan keluhan pasien tidak diketahui secara langsung yang seharusnya dengan tersedianya kotak saran maka pasien dapat menyampaikan keluhannya, sehingga pihak menajemen rumah sakit tidak dapat mengetahui secara pasti pelayanan apa yang dikeluhkan oleh pasien sehingga menghambat pihak manajemen dalam membuat kebijakan untuk meningkatan kualitas pelayanan di rawat jalan RSUD Kabupaten Indramayu.

Survey kepuasan menjadi penting dan perlu dilakukan bersamaan dengan pengukuran dimensi kualitas pelayanan kesehatan yang lain. Kemauan atau keinginan pasien dapat diketahui melalui survey kepuasan pasien. Oleh sebab itu, pengukuran kepuasan pasien perlu dilakukan secara berkala dan akurat.5

Oleh karena itu, peneliti tertarik untuk menganalisis "Hubungan kualitas pelayanan rawat jalan dengan kepuasan pasien Thalassemia di RSUD Kabupaten Indramayu Tahun 2018". 


\section{Metode}

Dalam penelitian ini, jenis penelitian yang digunakanadalah penelitian analitik observasional, dengan pendekatan cross sectional. Lokasi penelitian ini adalah Instalasi Rawat Jalan RSUD Kabupaten Indramayu. Dalam penelitian ini populasinya adalah seluruh pasien thalassemia yang berobat di poliklinik rawat jalan RSUD Kabupaten Indramayu tahun 2016, dengan jumlah sampel sebanyak 56 orang.

\section{Hasil}

Hasil univariat dalam penelitian ini meliputi karakteristik pasien, kualitas pelayanan kesehatan, distribusi frekuensi karakteristik pasien dan kepuasan pasien thalassemia. Hasil penelitian univariat disajikan dalam tabel 1-3.

\section{Distribusi Pasien thalassemia berdasarkan karakteristik responden}

Tabel 1. Distribusi Pasien thalassemia berdasarkan karakteristik responden di Rawat Jalan RSUD Indramayu tahun 2018

\begin{tabular}{cccc}
\hline Karakteristik & Kategori & N & \% \\
\hline \multirow{4}{*}{ Umur } & Balita & 2 & 3,6 \\
& Anak & 40 & 71,4 \\
& Remaja & 14 & 25,0 \\
\hline \multirow{2}{*}{ Jenis Kelamin } & Perempuan & 36 & 64,3 \\
& Laki-laki & 20 & 35,7 \\
\hline \multirow{5}{*}{ Pendidikan } & Belum & 11 & 19,6 \\
& Sekolah & 36 & 64,3 \\
& SD & 7 & 12,5 \\
& SMP & 2 & 3,6 \\
& SMA & & \\
\hline
\end{tabular}

Berdasarkan tabel 1 diketahui bahwa sebagian besar responden berusia anak-anak sebanyak $40(71,4 \%)$, lebih dari setengahnya berjenis kelamin perempuan sebanyak 36 (64,3\%), dan lebih dari setengahnya berpendidikan SD sebanyak 36 (64,3\%).

\section{Distribusi Kualitas Pelayanan Kesehatan}

Tabel 2. Distribusi Kualitas pelayanan kesehatan berdasarkan persepsi responden di Rawat Jalan RSUD Kabupaten Indramayu tahun 2018

\begin{tabular}{ccc}
\hline $\begin{array}{c}\text { Kualitas Pelayanan } \\
\text { Kesehatan }\end{array}$ & $\mathbf{N}$ & $\mathbf{\%}$ \\
\hline $\begin{array}{c}\text { Kurang Baik } \\
\text { Baik }\end{array}$ & 18 & 32,1 \\
\hline Total & $\mathbf{5 6}$ & $\mathbf{1 0 0 , 0}$ \\
\hline
\end{tabular}

Berdasarkan tabel 2, diketahui bahwa lebih dari setengahnya $(67,9 \%)$ pasien merasa kualitas pelayanan kesehatan rawat jalan di RSUD Kabupaten Indramayu sudah baik, dan hanya sebagian kecil $(32,1 \%)$ merasa masih kurang baik.

\section{Distribusi Kepuasan Pasien Thalasemia}

Tabel 3. Distribusi Kepuasan Pasien thalassemia berdasarkan persepsi responden di Rawat Jalan RSUD Kabupaten Indramayu Tahun 2018

\begin{tabular}{|c|c|c|}
\hline Kepuasan Pasien & $\mathbf{N}$ & $\%$ \\
\hline Kurang Puas & 20 & 35,7 \\
\hline Puas & 36 & 64,3 \\
\hline Total & 56 & 100,0 \\
\hline
\end{tabular}

Berdasarkan tabel 3, diketahui bahwa lebih dari setengahnya $(64,3 \%)$ pasien merasa puas terhadap pelayanan kesehatan rawat jalan di RSUD Kabupaten Indramayu, dan hanya $35,7 \%$ merasa kurang puas terhadap pelayanan kesehatan rawat jalan di RSUD Kabupaten Indramayu.

Dari hasil univariat meliputi karakteristik pasien, kualitas pelayanan kesehatan, distribusi frekuensi karakteristik pasien dan kepuasan pasien thalassemia telah didapatkan maka hasil bivariat juga dapat disajikan dalam tabel 4 mengenai Hubungan kualitas pelayanan kesehatan dengan kepuasan Pasien 


\section{Hubungan kualitas pelayanan kesehatan dengan kepuasan Pasien thalassemia}

Tabel 4. Hubungan kualitas pelayanan kesehatan dengan kepuasan Pasien thalassemia di Rawat Jalan RSUDKabupaten Indramayu tahun 2018

\begin{tabular}{|c|c|c|c|c|c|c|c|c|}
\hline \multirow{3}{*}{$\begin{array}{c}\text { Kualitas } \\
\text { Pelayanan } \\
\text { Kesehatan }\end{array}$} & \multicolumn{4}{|c|}{ Kepuasan Pasien } & \multirow{2}{*}{\multicolumn{2}{|c|}{ Total }} & \multirow{3}{*}{$\begin{array}{c}\text { OR }(95 \% \\
\text { CI })\end{array}$} & \multirow{3}{*}{ Nilai $p$} \\
\hline & \multicolumn{2}{|c|}{ Kurang Puas } & \multicolumn{2}{|c|}{ Puas } & & & & \\
\hline & $\mathbf{N}$ & $\%$ & $\mathbf{N}$ & $\%$ & $\mathbf{N}$ & $\%$ & & \\
\hline Kurang Baik & 14 & 77,8 & 4 & 22,2 & 18 & 100 & 18,66 & \\
\hline Baik & 6 & 15,8 & 32 & 84,2 & 38 & 100 & $(4,54-76,64)$ & 0,0001 \\
\hline Jumlah & 20 & 35,7 & 36 & 64,3 & 56 & 100 & & \\
\hline
\end{tabular}

Berdasarkan table 4, diketahui bahwa dari 18 pasien yang merasa kualitas pelayanan kesehatan di rawat jalan RSUD Indramayu kurang baik, namun masih merasa puas, dan dari 38 pasien yang merasa kualitas pelayanan kesehatan rawat jalan RSUD Kabupaten Indramayu sudah baik, terdapat 6 orang $(15,8 \%)$ pasien merasa kurang puas.

Hasil uji statistik menunjukkan bahwa ada hubungan antara kualitas pelayanan dengan kepuasan pasien, dengan nilai $\mathrm{p}<0,05$ yaitu sebesar 0,0001 . Hasil analisis didapatkan nilai OR sebesar 18,6, artinya pasien yang merasa bahwa kualitas pelayanan kesehatan rawat jalan di RSUD sudah baik akan berpeluang 18 kali lebih puas dibandingkan dengan pasien yang merasa kualitas pelayanan kesehatan kurang baik

\section{Pembahasan}

\section{Gambaran Kualitas Pelayanan Kesehatan berdasarkan Persepsi Pasien}

Berdasarkan hasil penelitian, diketahui bahwa lebih dari setengahnya $(67,9 \%)$ pasien merasa kualitas pelayanan kesehatan rawat jalan di RSUD Kabupaten Indramayu sudah baik, dan hanya sebagian kecil $(32,1 \%)$ merasa masih kurang baik.

Kualitas pelayanan kesehatan menurut pendapat Parasuraman, et al. dalam Purnama (2006) merupakan perbandingan antara layanan yang dirasakan (persepsi) konsumen dengan kualitas layanan yang diharapkan konsumen. Berdasarkan pendapat tersebut dapat diketahui bahwa kualitas pelayanan adalah memberikan kesempurnaan pelayanan untuk tercapainya keinginan atau harapan pelanggan. Apabila kualitas pelayanan yang dirasakan sama atau melebihi kualitas pelayanan yang diharapkan, maka layanan dikatakan berkualitas. $^{7}$

Kualitas pelayanan Rumah Sakit adalah standar pelayanan minimal yang dimaksudkan agar tersedianya panduan bagi daerah dalam melaksanakan perencanaan pelaksanaan, pengendalian, pengawasan dan pertanggungjawaban penyelenggaraan dalam memenuhi kebutuhan masyarakat atau pasien (Menteri Kesehatan Republik Indonesia, 2008).

Penelitian ini sesuai dengan penelitian yang dilakukan oleh Kumalasari (2009) yang menyatakan sebagian respondennya memiliki persepsi bahwa kualitas pelayanan di rawat inap bangsal Mawar 1 baik. Hal ini menunjukkan bahwa kualitas pelayanan yang diberikan Instalasi Rawat Jalan di RSUD Kabupaten Indramayu sudah baik. ${ }^{8}$

\section{Gambaran Kepuasan Pasien Thalasemia terhadap Pelayanan Kesehatan}

Berdasarkan hasil penelitan, diketahui bahwa lebih dari setengahnya $(64,3 \%)$ pasien merasa puas terhadap pelayanan kesehatan rawat jalan di RSUD Kabupaten Indramayu, dan hanya $35,7 \%$ merasa kurang puas terhadap 
pelayanan kesehatan rawat jalan di RSUD KabupatenIndramayu.

Kepuasan merupakan perasaan senang seseorang yang berasal dari perbandingan antara kesenangan terhadap aktivitas dan suatu produk dengan harapannya merupakan pengertian kepuasan. Kepuasan pasien merupakan salah satu ukuran keberhasilan pelayanan yang diberikan rumah sakit. Rumah sakit sebagai pemberi jasa pelayanan harus memuaskan masyarakat sebagai pengguna jasa. Mutu pelayanan rumah sakit sangat dipengaruhi oleh kualitas sarana fisik, jenis tenaga yang tersedia, obat dan alat kesehatan, serta proses pemberian pelayanan (Triwibowo, 2013). ${ }^{9}$

Penelitian ini sesuai dengan penelitian yang dilakukan Hayaza (2013) mengemukakan bahwa sebagian respondennya merasa cukup puas terhadap pelayanan kesehatan di Rumah Sakit PKU Muhammadiyah yaitu dengan total nilai $75 \%$. Berdasarkan uraian diatas dapat disimpulkan bahwa kepuasan responden terhadap pelayanan di pelayanan kesehatan rawat jalan di RSUD Indramayu sebagian besar sudah sesuai dengan harapan yang diinginkan oleh responden tersebut. ${ }^{10}$

\section{Hubungan kualitas pelayanan kesehatan dengan kepuasan Pasien thalassemia}

Berdasarkan hasil penelitian, diketahui bahwa dari 18 pasien yang merasa kualitas pelayanan kesehatan di rawat jalan RSUD Indramayu kurang baik, namun masih merasa puas, dan dari 38 pasien yang merasa kualitas pelayanan kesehatan rawat jalan RSUD Indramayu sudah baik, terdapat 6 orang $(15,8 \%)$ pasien merasa kurang puas.

Hasil uji statistik menunjukkan bahwa ada hubungan antara kualitas pelayanan dengan kepuasan pasien, dengan nilai $\mathrm{p}<0,05$. Hasil analisis didapatkan nilai OR sebesar 18,6, artinya pasien yang merasa bahwa kualitas pelayanan kesehatan rawat jalan di RSUD sudah baik akan berpeluang 18 kali lebih puas dibandingkan dengan pasien yang merasa kualitas pelayanan kesehatan kurang baik

Menurut Tjiptono (2005) pelayanan kesehatan yang berkualitas akan memberikan kepuasan kepada pasien yang menerima pelayanan tersebut. Kualitas pelayanan yang rendah dapat menyebabkan banyaknya keluhan pelanggan, bila hal ini tidak diatasi dengan baik maka perusahaan akan kehilangan pelanggannya. Upaya pelayanan haruslah memberi kepuasan, tidak semata-mata sembuh belaka. $^{11}$

Kualitas pelayanan dapat dilihat dari lima dimensi service quality yang dikembangkan Parasuraman dkk (1991), bertujuan sebagai instrumen untuk mengukur kualitas pelayanan dengan mengukur selisih antara harapan konsumen terhadap kinerja pelayanan dengan pelayanan yang sebenarnya. Ada lima dimensi yang dapat diaplikasikan pada setiap penyedia jasa untuk mengukur kualitas pelayanan. Lima dimensi yang diukur dari pelayanan tersebut adalah dimensi bukti fisik (tangible), keandalan (reliability), daya tanggap (responsiveness) kepastian (assurance), dan empati (emphaty) (Parasuraman dkk, 1991). ${ }^{12}$

Pengukuran tingkat kepuasan pasien Jaminan Kesehatan Nasional penting dilakukan karena telah diamanatkan dalam Peraturan Presiden Republik Indonesia Nomor 12 Tahun 2013 tentang Jaminan Kesehatan pasal 42, bahwa pelayanan kesehatan yang diberikan kepada peserta jaminan kesehatan harus memperhatikan mutu pelayanan. Untuk mengetahui bermutu atau tidaknya pelayanan yang diberikan dapat dilihat dari kepuasan pasien yang mengakses pelayanan kesehatan.

Hasil penelitian ini sejalan dengan hasil penelitian yang dilakukan oleh Supriyati (2004) yang menyimpulkan bahwa semakin tinggi mutu pelayanan keperawatan, maka semakin tinggi tingkat kepuasan yang dirasakan oleh pasien. Perbedaannya adalah pada subyek dan lokasi yang diteliti. Penelitian yang dilakukan oleh Kumalasari (2009) menunjukkan ada hubungan yang signifikan 
antara kualitas pelayanan rawat inap dengan tingkat kepuasan pasien di bangsal Mawar 1 RSUD Dr. Moewardi Surakarta.

Agar dapat memantau kualitas pelayanan yang telah diberikan, maka rumah sakit diharapkan melakukan survei rutin secara berkala untuk menilai langsung kualitas layanan yang tersedia dibandingkan dengan yang diharapkan dan survei tentang kepuasan pasien. Meningkatkan perhatian kepada pasien thalasemia, mengutamakan kepentingan pasien thalasemia, memahami kebutuhan pasien thalasemia yang maksimal.

\section{Kesimpulan}

Setelah melakukan penelitian tentang hubungan kualitas pelayanan rawat jalan dengan kepuasan pasien thalassemia di RSUD Kabupaten Indramayu tahun 2018, maka penulis dapat mengambil kesimpulan sebagai berikut:

1. Pasien thalassemia terbanyak adalah anakanak sebanyak 40 orang $(71,4 \%)$ dan berjenis kelamin perempuan sebanyak 36 orang $(64,3 \%)$ serta masih berpendidikan SD yaitu sebanyak 36 orang $(64,3 \%)$.

2. Pasien yang merasa kualitas pelayanan rawat jalan di RSUD Kabupaten Indramayu sudah baik sebanyak $67,9 \%$.

3. Pasien yang merasa puas terhadap pelayanan rawat jalan di RSUD Kabupaten Indramayusebanyak64,3\%.

4. Terdapat hubungan antara kualitas pelayanan rawat jalan dengan kepuasan pasien thalassemia di RSUD Kabupaten Indramayu dengan $\mathrm{p}$ value 0,0001 yaitu kurang dari 0,05 .

\section{Saran}

Berdasarkan hasil penelitian yang telah diperoleh ada beberapa saran yang perlu dijadikan pertimbangan bagi peneliti dan penelitian antara lain:
1. Bagi Institusi Pendidikan

a. Perlu dilakukan lagi penelitian lebih lanjut mengenai hubungan kualitas pelayanan kesehatan dengan kepuasan pasien.

b. Sebagai bahan masukan dalam proses belajar mengajar dan penelitian khususnya tentang kualitas pelayanan kesehatan dengan kepuasan pasien.

2. Bagi Petugas di RSUD Kabupaten Indramayu.

Perlu dipertahankan dan ditingkatkan lagi kinerja keperawatan dengan bekerja sesuai dengan SOP, memperhatikan kaidahkaidah dan etika keperawatan sehingga terwujud pelayanan keperawatan yang optimal.

3. Bagi RSUD Kabupaten Indramayu

Diharapkan dari manajemen rumah sakit dapat lebih banyak lagi mengirim tenaga perawat untuk mengikuti seminar dan pelatihan kerja untuk meningkatkan kinerja perawat pelaksana sehingga kualitas pelayanan kesehatan semakin optimal dan terwujudnya kepuasan pasien.

\section{Daftar Pustaka}

1. Manurung. 2010. Manajemen Kualitas Kesehatan. Edisi Kedua. Jakarta : Penerbit Buku Kedokteran EGC

2. Ngastiyah, 2005. Perawatan Anak Sakit Edisi 2. Jakarta: EGC

3. Indriati, Ganis. 2011. Pengalaman Ibu Dalam Merawat Anak Dengan Thalassemia di Jakarta. Jakarta: Universitas Indonesia

4. Suriadi dan Rita Y. 2001. Asuhan Keperawatan pada Anak, Edisi 1. Jakarta: CV. Agung Seto

5. Pohan, Imbolo, 2007. Jaminan Mutu Layanan Kesehatan. Penerbit Buku Kedokteran ECG, Jakarta

6. Purnama, Nursya'bani. 2006. Manajemen Kualitas: Perspektif Global. Yogyakarta: Ekonisia 
7. Depkes, Permenkes RI, No. 269/MenKes/Per/III/2008, Tentang Rekam Medis. (Jakarta: Depkes RI. 2008)

8. Kumalasari. 2009. Analisis Pengaruh Kualitas Pelayanan Terhadap Kepuasan Pasien Di RS Triadipa Jakarta. Skripsi. URINDO

9. Triwibowo. 2013. Manajemen pelayanan keperawatan di rumah sakit. Jakarta: TIM.

10. Hayaza. 2013. Hubungan pelayanan kesehatan dengan kepuasan pasien di instalasi rawat inap Rumah Sakit PKU MUhammadiyah. Skripsi: UMS

11. Tjiptono. 2001. Manajemen Pemasaran dan Analisa Perilaku Konsumen, Yogyakarta: BPFE.

12. Supriyati. 2004. Analisa Pengaruh Mutu Layanan terhadap Kepuasan Pasien di Rumah Sakit Haji Surabaya. Jurnal Manajemen Kesehatan. Vol 1. No 1 